\title{
Distribution of Cellulase Activities in Acetes Shrimps Living in the Matang Mangrove Forest Reserve, Malaysia
}

\author{
Aya Tanimura ${ }^{1}$, Takatoshi Niiyama ${ }^{1}$, Yukio Hanamura ${ }^{2}$, Tomoyuki Okutsu ${ }^{3}$, Haruhiko Toyohara ${ }^{1}$, \\ Katsuhisa Tanaka ${ }^{3 *}$ and Alias Man $^{4}$
}

\author{
${ }^{1}$ Division of Applied Biosciences, Graduate School of Agriculture, Kyoto University, Kitashirakawa, Sakyo, Kyoto 606-8502, \\ Japan. \\ ${ }^{2}$ National Research Institute of Fisheries Science, Fishery Research Agency, Fukuura, Kanazawa, Yokohama 236-8648, Japan. \\ ${ }^{3}$ Japan International Research Center for Agricultural Sciences, Owashi, Tsukuba 305-8686, Japan. \\ ${ }^{4}$ Fisheries Research Institute, Kampung Acheh, 32000 Sitiawan, Perak, Malaysia.
}

"katuhi@affrc.go.jp (Corresponding author)

\begin{abstract}
For the purpose of investigating the cellulose degradation mechanism in mangrove estuaries, cellulase activities of three Acetes shrimps (Acetes sibogae, A. japonicus and A. indicus) were examined in the Matang Mangrove Forest Reserve (MMFR). As a result of cellulose plate assay measurement, we detected the activities from all three species. SDS-PAGE zymographic analysis revealed that all Acetes shrimps demonstrated active bands at approximately $25 \mathrm{kDa}$ and higher than $100 \mathrm{kDa}$. In addition, by quantification of reducing sugar production, hepatopancreas samples of Acetes showed significantly higher cellulase activity compared to whole body samples suggesting their endogenous origin. Our findings that cellulase activities are widely distributed among the Acetes shrimps living in the MMFR, suggests that mangroves are indirectly utilized by higher trophic consumers.
\end{abstract}

(Keywords: cellulase, mangrove, Acetes, hepatopancreas)

\section{INTRODUCTION}

There is a unique ecological system in mangrove areas which develops extraordinary high biological productivity [1]. Roots of mangrove trees function as refuges for larval fish and mangrove litter is well utilized as carbon source for some organisms living in the mangrove estuary [1]. The Matang Mangrove Forest Reserve (MMFR), situated on the northwestern coast of Peninsular Malaysia, is reputed to be the world's best managed mangrove forest. The reserve is the largest single tract of mangrove forest in Peninsular Malaysia (40,151 ha) where abundant Acetes shrimps are well fed by the larger predators [1]. Thus, it is important to validate the food chain derived from mangrove in terms of nutritional aspect to maintain sustainable utilization of fishery resources. Despite the elaborate efforts of fatty acid analysis and stable isotopic analysis to elucidate the food chain in the mangrove ecosystem, biochemical degradation process of mangrove litter still remains unclear [1-7].

Cellulose, most abundant organic substance on the earth, is a high molecular weight compounds composing of glucose bound by $\beta-1,4$ linkages $[8,9]$. Cellulose is a main component of plant cell wall and makes rigid superstructure known as cellulosemicrofibril. Thus, cellulose is resistant to degradation. Cellulase, which is a collective name of enzymes degrading cellulose, is classified into two subtypes such as an endo- $\beta$-1,4-glucanase (EC 3.2.1.4.) and a cellobiohydrolase (EC3.2.1.91.) [9, 10]. Glucose dimmers or oligosaccharides generated by these enzymes are further degraded by $\beta$-glycosidase (EC 3.2.1.21.) into glucose which is well utilized by various organisms [9]. Most studies on cellulase are focused on endo$\beta$-1,4-glucanase, thus we used "cellulase" to indicate endo- $\beta-1,4$-glucanase in the present study. Recently, cellulase genes located on the chromosomes of some crustaceans, abalone and bivalves have been reported [11-15]. Also, Niiyama and Toyohara [16] detected the widespread presence of cellulase and hemicellulase activity among aquatic benthos, whereas King et al. [17] proposed self wood-digesting system of an aquatic isopod Limnoriidae. These findings suggest that aquatic invertebrates are possibly involved in cellulase degradation in the environment and subsequently play ecologically important roles in the aquatic food chain.

In the present study, in order to validate the implication of these animals in cellulose degradation, we made an 
attempt to detect cellulase activities from Acetes shrimps in the MMFR.

\section{MATERIALS AND METHODS}

\section{Animals}

Sampling locations in the Matang Mangrove Forest Reserve are shown in Fig. 1. Sampling was carried out at two stations named R2 and C3 according to the locations of Tanaka et al. [18]. Station R2 is located in a place near the mudflat, where is approximately $2 \mathrm{~km}$ off from the shore. Station C3 is located in the creek. We collected three dominant species of Acetes shrimps (Acetes japonicus at Station R2, A. sibogae at Station C3 and A. indicus at Station R2) in July 29, 2010 and September 28, 2012. A small hand dip net and a sledge net were used to collect the samples and the shrimps were pick up artificially from the net. A. indicus and $A$. japonicus were known to be abundant around offshore, whereas A. sibogae has a tendency to be distributed in the middle to upper reaches [19]. Samples were kept on ice in the field and frozen $\left(-32^{\circ} \mathrm{C}\right)$ in the laboratory until analysis. In the laboratory, the carapace length was measured as the standard length (Table 1). All procedure was based on Tanaka et al. [18].

\section{Measurement of cellulase activities by agar plate assay}

According to the method of Sakamoto and Toyohara [14], $1.5 \%$ agar plate containing $0.5 \%$ carboxymethylcellulose (CMC, Sigma) was prepared. For measurement of enzymatic activity, intestine (approximately $3 \mathrm{~cm}$ in length) was picked out from a few individuals of each Acetes shrimps and homogenized $(2 \mu 1)$. The homogenate was prepared by grinding samples using a plastic pestle in a plastic tube. The prepared samples were placed on the agar plate, and the plates were incubated at $37^{\circ} \mathrm{C}$ for overnight. Then, these plates were stained by $0.1 \%$ Congo Red for $3 \mathrm{~h}$ followed by destaining with $1 \mathrm{M} \mathrm{NaCl}$. Cellulase activity was detected as an unstained circle.

\section{Analysis of molecular elements of cellulases by SDS-PAGE zymography}

According to the method of Beguin [20], $7.5 \%$ polyacrylamide gel containing $\mathrm{CMC}$ was used for the detection of molecular species of cellulases. In order to detect clear band, concentration of CMC is optimized to $0.5 \%$. Intestines of each species of Acetes dissected from two or three individuals were mixed and used for analysis. For electrophoresis, $10 \mu \mathrm{l}$ of phosphate buffered saline (PBS) containing $140 \mathrm{mM} \mathrm{NaCl}, 2.7 \mathrm{mM}$ $\mathrm{KCl}, 8 \mathrm{mMNa}_{2} \mathrm{HPO}_{4}, 1.5 \mathrm{mM} \mathrm{KH}_{2} \mathrm{PO}_{4}(\mathrm{pH} 7.4)$ and $2 \mu \mathrm{l}$ of $6 \times$ SDS sample buffer containing $0.6 \mathrm{M}$ Tris $-\mathrm{HCl}(\mathrm{pH}$ 6.8 ), $60 \%$ glycerol, $6 \%$ SDS and $0.06 \%$ bromophenol blue were added to the homogenate $(3 \mu \mathrm{l})$ of Acetes shrimps. After electrophoresis, the gel was washed by $0.1 \mathrm{M}$ acetate buffer $(\mathrm{pH} 5.5)$ containing $0.1 \%$ TritonX-100 for $30 \mathrm{~min}$ and soaked into $0.1 \mathrm{M}$ acetate buffer (pH 5.5). After incubation at $37^{\circ} \mathrm{C}$ for overnight, the gel was stained and destained as described above. Destained gel was soaked into $1 \mathrm{M}$ acetate to detect active bands clearly. Active bands were detected as unstained transparent bands.

\section{Colorimetric measurement of cellulase activity}

Hepatopancreas was dissected out from 50 specimens for two Acetes species (A. sibogae and A. indicus) which were collected in September 28, 2012, and homogenized in $40 \mu \mathrm{l}$ PBS buffer. Also, whole body of three individuals for each species was homogenized in $1 \mathrm{ml}$ PBS buffer. The supernatants of the homogenate samples, namely enzyme solution, were used for further analysis. Protein concentration of the enzyme solution was measured by the method of Bradford [21], and adjusted at $1 \mathrm{mg} \mathrm{ml}^{-1}$ with PBS buffer and stored at $-32^{\circ} \mathrm{C}$ until the measurement. Bovine serum albumin was used as the standard for the determination of the protein concentration.

According to the method of Niiyama and Toyohara [16], $5 \mu$ enzyme solution, whose protein concentration was $1 \mathrm{mg} / \mathrm{ml}$, was mixed with $5 \mu \mathrm{l}$ of $1 \mathrm{M}$ sodium acetate buffer ( $\mathrm{pH} 5.5$ ), and $40 \mu \mathrm{l}$ of the substrate solution (CMC). After the incubation at $37^{\circ} \mathrm{C}$ for $10 \mathrm{~min}$ for the enzymatic reaction, mixtures were heated at $100^{\circ} \mathrm{C}$ to terminate the reaction. The amount of reducing sugar produced was measured by the tetrazolium blue method by the absorbance at $660 \mathrm{~nm}$ according to Jue and Lipke [22]. D-Glucose was used as the standard for the determination of the amount of reducing sugar.

\section{RESULTS}

\section{Occurrence of cellulase in Acetes shrimps}

As shown in Fig. 2, cellulase activities were detected by cellulose plate assay as unstained circles from all the 
three species of Acetes. Paticulary, A. sibogae showed clear unstained circle whereas $A$. japonicas and $A$. indicus showed faint and small circles, suggesting that A. sibogae has significant higher cellulase activity than the others.

By SDS-PAGE zymography, three species of Acetes commonly exhibited two clear active bands (Fig. 3). A. sibogae exhibited $200 \mathrm{kDa}$ and $26 \mathrm{kDa}$ bands, $150 \mathrm{kDa}$ and $24 \mathrm{kDa}$ bands in A. japonicus, and exhibited 120 $\mathrm{kDa}$ and $24 \mathrm{kDa}$ bands in $\mathrm{A}$. indicus.

\section{Differentiation of cellulase activity among Acetes shrimps}

As shown in Fig. 4, reducing sugar produced by cellulase was quantified in the two species of Acetes (A. sibogae and $A$. indicus). Hepatopancreas samples represented significantly higher enzymatic activity compared to the whole body samples. (Whole body of A. indicus: $0.02985 \mu \mathrm{mol} \mathrm{min}{ }^{-1} \mathrm{mg}$ protein ${ }^{-1}$, hepatopancreas of A. indicus: $0.927 \mu \mathrm{mol} \mathrm{min}^{-1} \mathrm{mg}$ protein ${ }^{-1}$, whole body of A. sibogae: $0.0154 \mu \mathrm{mol} \mathrm{min}{ }^{-1} \mathrm{mg}$ protein ${ }^{-1}$ and hepatopancreas of $A$. sibogae: $0.531 \mu \mathrm{mol} \mathrm{min}{ }^{-1} \mathrm{mg}$ protein $\left.^{-1}\right)$.

\section{DISCUSSION}

We have successfully detected cellulase activities from all the three species of Acetes examined, suggesting that the Acetes shrimps living in the mangrove estuary have cellulase as digestive enzyme (Figs. 2, 3 and 4).

This is the first report to prove on the occurrence of cellulase in Acetes shrimps, although cellulase activities including the reports of endogenous genes encoding cellulase have been already reported from several crustaceans such as crayfishes and crabs [11, 23-26]. In addition, the occurrence of multiple forms of cellulases is also found from all species of Acetes, although assimilation and digestion of cellulose in mysids have been studied and their endogenous occurrence of cellulase has been previously speculated [27-29]. The hepatopancreas samples demonstrated significantly higher enzymatic activity compared to the whole body samples in the two species tested, supporting the speculation of endogenous occurrence.

By means of SDS-PAGE zymographic analysis, all three species of Acetes demonstrated two active bands; one is approximately $25 \mathrm{kDa}$ and the other is higher than 100
$\mathrm{kDa}$ as shown in Fig. 3. In crustaceans, the molecular weight of cellulases, $40 \mathrm{kDa}$ (Cherax quadricarinatus), $53 \pm 3 \mathrm{kDa}$ and $52 \mathrm{kDa}(C$. destructor) and $52 \mathrm{kDa}$ (Gecarvoidea natalis) have been previously reported $[23,26]$, and these values differed from those found in the present study (Fig. 3). This result suggests that cellulases of Acetes shrimps are possibly novel and specific. It requires further study to determine whether these active bands of the Acetes shrimps are derived from enzymes encoded on the chromosomal genes as in the case of Cherax quadricarinatus [11] or from enzymes of parasitic microorganisms. We are now trying to isolate genes encoding these cellulases to determine their origin.

Our study has suggested that the dominant Acetes shrimps in the MMFR have endogenous cellulase because hepatopancreas samples represented significantly higher values compared to the whole body samples (Fig. 4). Hepatopancreas is known as the secretary organ in arthropods, mollusks and fish. In crustaceans, it provides the functions of both liver and pancreas in mammals; production and secretion of several digestive enzymes, uptake of nutrition, and storage of carbon source [30]. Thus, the presence of symbiotic microorganism is unlikely to produce cellulase in hepatopancreas, as previously reported by King et al. [17].

Among the Acetes shrimps tested in the present study, A. sibogae is a dominant species in the inner mangrove estuary, while A. japonicas and A. indicus are mainly distributed from the river mouth to the shallow coastal area [18]. In the previous studies, fresh water shrimps exhibited higher cellulase activities than seawater shrimp species [31]. Interestingly, a similar result was found in the present study on the result of plate assay, in which cellulase activity level is higher in A. sibogae than the other species (Fig. 2).

The three species of Acetes studied in the present study are assumed to play ecologically important roles in the estuaries of the MMFR as foods for other higher consumers in the food chain since the main prey items of John's snapper (Lutjanus johnii) and banana prawn (Fenneropenaeus merguiensis) are Acetes shrimps (the volumetric composition of Acetes shrimps constituted $37-43 \%$ of total stomach contents of John's snapper, and $40-50 \%$ of stomach contents of banana prawn captured in shallow coasts were mysids and Acetes shrimps) [3234]. Moreover, juvenile John's snapper migrate into the upstream mangrove area where Acetes shrimps were more abundant [18]. Detection of enzymatic activity could confirm the food source speculation by gut content 
investigation or stable isotope analysis, and contribute significantly to the determination of food web in the mangrove estuary.

This is the first report showing that Acetes shrimps species in the MMFR have significant cellulase activity. Also, these species were speculated to have endogenous cellulase in their hepatopancreas, which has the common character in molecular size. These findings strongly suggest that Acetes shrimps can digest cellulose as their food source, and subsequently, mangroves are indirectly utilized by higher trophic consumers. To validate the assimilation of cellulose derived from mangroves, further studies are required coupled with examination of stomach contents of Acetes shrimps and stable isotopic analysis.

\section{ACKNOWLEDGEMENTS}

This study was supported by a Grant-in-Aids for Scientific Research from the Ministry of Education, Culture, Sports, Science and Technology of Japan (No. 22255012 and No. 22405030). The authors gratefully acknowledge permission by the Department of Fisheries, Government of Malaysia, to carry out the research in the mangrove area. Appreciation is also expressed to the Fisheries Research Institute for providing various facilities for this study. The study was funded in part by the Japan International Research Center for Agricultural Sciences.

\section{REFERENCES}

1. Chong, V. C. (2007). Mangroves-fisheries linkages -the Malaysian perspective. Bulletin of Marine Science 80: 755-772.

2. Bachok, Z., Mfilinge, P. L., and Tsuchiya, M. (2003). The diet of the mud clam Geloina coaxans (Mollusca, Bivalvia) as indicated by fatty acid markers in a subtropical mangrove forest of Okinawa, Japan. Journal of Expermental Marine Biology and Ecology 292: 187-197.

3. Bouillona, S., Koedamb, N., Baeyensa, W., and Satyanarayana, B., Dehairs, F. (2004).. Selectivity of subtidal benthic invertebrate communities for local microalgal production in an estuarine mangrove ecosystem during the post-monsoon period. Journal of Sea Research 51: 133-144.

4. Bouillon, S., Connolly, R. M., and Lee, S. Y. (2008). Organic matter exchange and cycling in mangrove ecosystems: Recent insights from stable isotope studies. Journal of Sea Research 59: 44-58.

5. Chong, V. C., Low, C. B., and Ichikawa, T. (2001). Contribution of mangrove detritus to juvenile prawn nutrition: a dual stable isotope study in a Malaysian mangrove forest. Marine Biology 138: 77-86.

6. Loneragan, N.R., Bunn, S. E., and Kellaway, D. M. (1997). Are mangroves and seagrasses sources of organic carbon for penaeid prawns in a tropical Australian estuary? A multiple stable-isotope study. Marine Biology 130: 289-300.

7. Meziane, T. and Tsuchiya, M. (2000). Fatty acids as tracers of organic matter in the sediment and food web of a mangrove/intertidal flat ecosystem, Okinawa, Japan. Marine Ecology Progress Series 200: 49-57.

8. Cosgrove, D. J. (2005). Growth of the plant cell wall. Nature Reviews Molecular Cellular Biology 6: 850-861.

9. Vries, R.P. and Visser, J. (2001). Aspergillus enzymes involved in degradation of plant cell wall polysaccharides. Microbiology and Molecular Biology Reviews 65: 497-522.

10. Henrissat, B., Claeyssen, M., Tomme, P., Lemesle, L. and Mornon, J.P. (1989). Cellulase families revealed by hydrophobic cluster analysis. Gene 81: 83-95.

11. Byrne, K. A., Lehnert, S.A., Johnson, S. E. and Moore, S. S. (1999). Isolation of a cDNA encoding a putative cellulase in the red claw crayfish Cherax quadricarinatus. Gene 239: 317-324.

12. Nikapitiya, C., Oh, C., Zoysa, M., Whang, I., Kang, D. H., Lee, S. R., Kim, S. J. and Lee, J. (2010). Characterization of beta-1,4-endoglucanase as a polysaccharide-degrading digestive enzyme from disk abalone, Haliotis discus discus. Aquaculture International 18: 1061-1078.

13. Sakamoto, K., Touhata, K., Yamashita, M., Kasai, A., and Toyohara, H. (2007). Cellulose digestion by common Japanese freshwater clam Corbicula japonica. Fisheries Science 73: 675-683.

14. Sakamoto, K. and Toyohara, H. (2009). A comparative study of cellulase and hemicellulase activities of brackish water clam Corbicula japonica with those of other marine Veneroida bivalves. Journal of Experimental Biology 212: 2812-2818.

15. Suzuki, K., Ojima, T. and Nishita, K. (2003). Purification and cDNA cloning of a cellulase from abalone Haliotis discus hannai. European Journal of Biochemistry 270: 771-778. 
16. Niiyama, T. and Toyohara, H. (2011). Widespread distribution of cellulase and hemicellulase activities among aquatic invertebrates. Fisheries Science 77: 649-655.

17. King, A.J. et al. (2010). Molecular insight into lignocelluloses digestion by a marine isopod in the absence of gut microbes. Proceedings of the National Academy Sciences of the U.S.A. 107: 5345-5350.

18. Tanaka, K., Hanamura, Y., Chong, V. C., Watanabe, S., Man, A., Kassim, F. M., Kodama, M., and Ichikawa, T. (2011). Stable isotope analysis reveals ontogenetic migration and the importance of a large mangrove estuary as a feeding ground for juvenile John's snapper Lutjanus johnii. Fisheries Science 77: 809-816.

19. Hanamura, Y., Siow, R., Chee, PE. (2007) Abundance and spatio-temporal distribution of hyperbenthic crustaceans in the Merbok and Matang Mangrove Estuary, Malaysia. JIRCAS Working Report 56: 35-42.

20. Beguin, P. (1983). Detection of cellulase activity in polyacrylamide gels using Congo red-stained agar replicas. Analytical Biochemistry 131: 333-336.

21. Bradford, M. M. (1976). A rapid and sensitive method for the quantification of microgram quantities of protein utilizing the principle of protein- dye binding. Analytical Biochemistry 72: 248-254.

22. Jue, C. K. and Lipke, P. N. (1985). Determination of reducing sugars in the nanomole range with tetrazolium blue. Journal of Biochemical and Biophysical Methods 11:109-115.

23. Allardyce, B. J. and Linton, S. M. (2008). Purification and characterization of endo-beta1,4-glucanase and laminarinase enzymes from the gecarcinid land crab Gecarcoidea natalis and the aquatic crayfish Cherax destructor. Journal of Experimental Biology 211: 2275-2287.

24. Linton, S. M. and Greenaway, P. (2004). Presence and properties of cellulase and hemicellulase enzymes of the gecarcinid land crabs Gecarcoidea natalis and Discoplax hirtipes. Journal of Experimental Biology 207: 4095-4104.

25. Linton, S. M., Greenaway, P. and Towle, D. W. (2006). Endogenous production of endo- $\beta-1,4-$ glucanase by decapod crustaceans. Journal of Comparative Physiology B 176: 339-348.

26. Xue, X. M., Anderson, A. J., Richardson, N. A., Anderson, A. J., Xue, G. P. and Mather, P. B. (1999). Characterization of cellulase activity in the digestive system of the redclaw crayfish (Cherax quadricarinatus). Aquaculture 180: 373-386.
27. Foulds, J. B. and Mann, K. H. (1978). Cellulose digestion in Mysis stenolepis and its ecological implications. Limnology and Oceanography 23: 760-766

28. Friesen, J. A., Mann, H. and Novitsky, J. A. (1986). Mysis digests cellulose in the absence of a gut microflora. Canadian Journal of Zoology 62: 442-446.

29. Zagursky, G. and Feller, R. J. (1985). Macrophyte detritus in the winter diet of the estuarine mysid, Neomysis americana. Estuaries 8: 355-362.

30. Brunet, M., Arnaud, J. and Mazza, J. (1994). Gut structure and digestive cellular processes in marine Crustacea. Oceanography and Marine Biology: an annual review 32:335-367.

31. Crawford, A. C., Richardson, N. R. and Mather, P. B. (2005). A comparative study of cellulase and xylanase activity in freshwater crayfish and marine prawns. Aquaculture Research 36: 586-592.

32. Chong, V. C. and Sasekumar, A. (1981). Food and feeding habits of the white prawn Penaeus merguiensis. Marine Ecology Progress Series 5: 185-191.

33. Kiso, K. and Mahyam, M. I. (2003). Distribution and feeding habits of juvenile and young John's snapper Lutjanus johnii in the Matang mangrove estuary, west coast of Peninsular Malaysia. Fisheries Science 69: 563-568.

34. Amy Then, Y.H., Chong, V. C., Moh, H. H. and Hanamura, Y. (2006) Size frequency abundance and feeding habits of young snappers (Lutjanus spp.) and groupers (Epinephelus spp.) in the Matang Mangrove Estuary, Malaysia. JIRCAS Working Report 44:1-5 


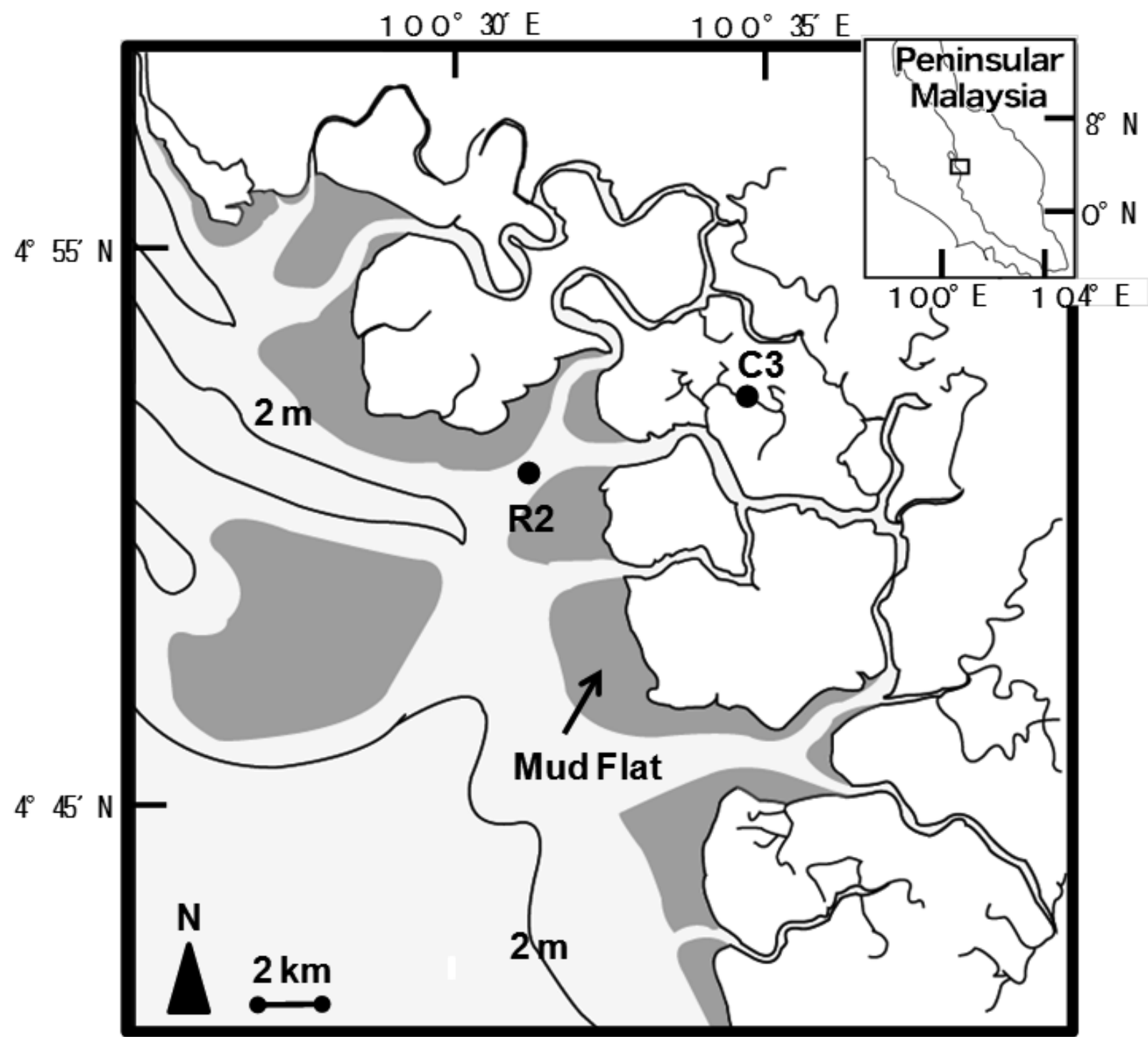

Figure 1. Sampling sites (filled circle) of Acetes shrimps in the Matang Mangrove Forest Reserve in the west of Peninsular Malaysia.

Table 1. Acetes shrimps used in the present study. Three species of Acetes were collected on the below date in the MMFR.

\begin{tabular}{lllll}
\hline Order & Species & Site & Date & Carapace Length (mm) \\
\hline Decapoda, Sergestidae & Acetes indicus & R2 & July 29, 2010 & $2.5-4.5$ \\
& & R2 & Sep. 28, 2012 & $5.0-6.5$ \\
& Acetes japonicus & R2 & July 29, 2010 & $3.0-4.5$ \\
& Acetes sibogae & C3 & July 28, 2010 & $2.5-4.5$ \\
& & C3 & Sep.28, 2012 & $2.5-4.5$ \\
\hline
\end{tabular}




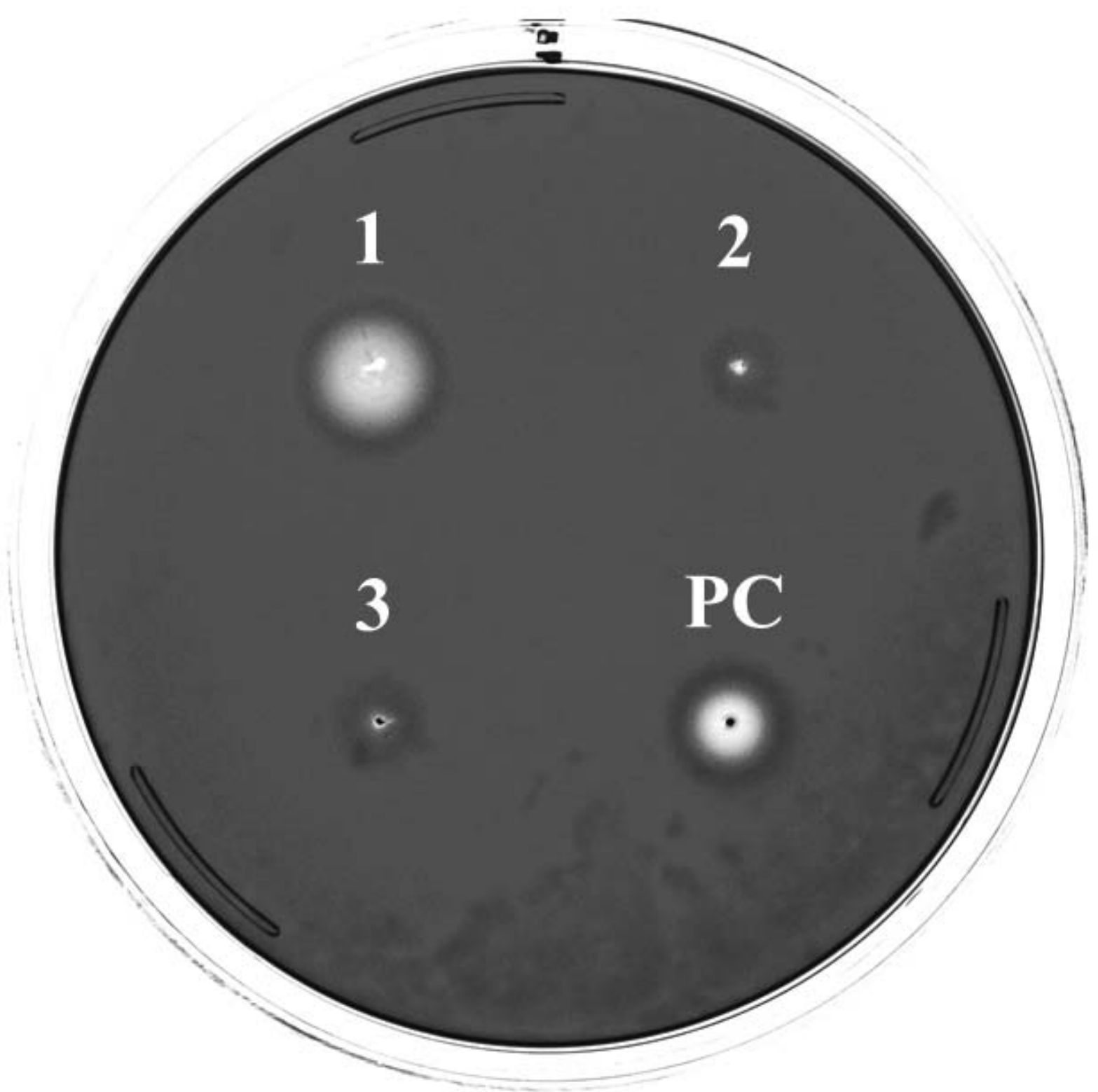

Figure 2. Detection of cellulase enzymatic activity by Plate Assay Analysis of Acetes shrimps collected in July 2010. Cellulase activity was detected as unstained circle by Congo Red. 1: Acetes sibogae 2: Acetes japonicus 3: Acetes indicus. Commercially obtained cellulase (MP Biomedicals) was used in PC (Positive control). 


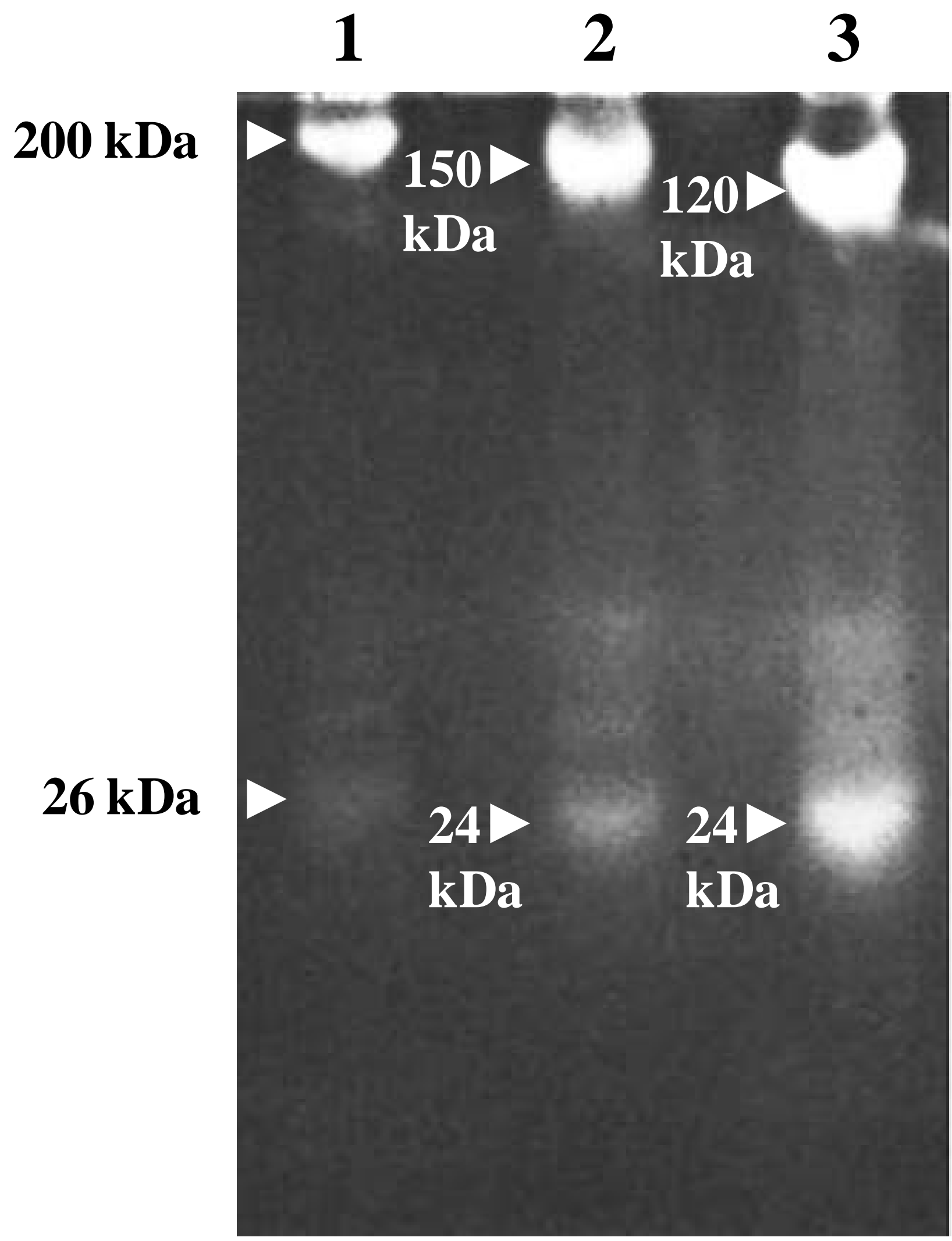

Figure 3. Zymographic analysis of Acetes shrimps collected in July 2010. Cellulase enzymatic activity was detected as unstained band by Congo Red. 1: Acetes sibogae 2: Acetes japonicus 3: Acetes indicus 

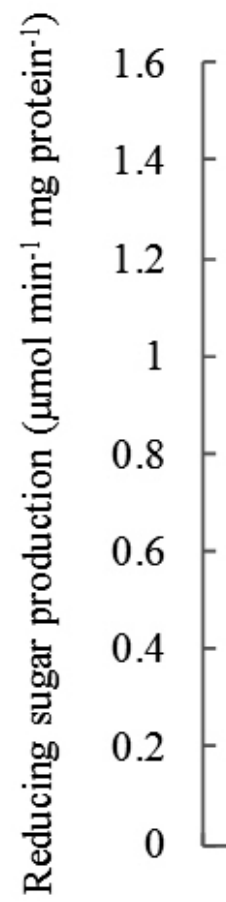
Malaysian Journal of Science 32 (SCS Sp Issue) : 1-10 (2013) 